\section{B A Institute of \\ YK Business Administration \\ 光 \\ Karachi \\ Leadership and Ideas for Tomorrow}

Business Review

Volume 14 Issue 2 July-December 2019

7-1-2019

\title{
Entrepreneurship in Pakistan: A comparative assessment of the role played by perceptions
}

\author{
Talha Nadeem \\ Economic Policy Review Department, State Bank of Pakistan \\ Mohammad Nishat \\ Institute of Business Administration, Karachi, Pakistan \\ Farooq Pasha \\ Research Department, State Bank of Pakistan
}

Follow this and additional works at: https://ir.iba.edu.pk/businessreview

\section{(c) (9)}

This work is licensed under a Creative Commons Attribution 4.0 International License.

\section{Recommended Citation}

Nadeem, T., Nishat, M., \& Pasha, F. (2019). Entrepreneurship in Pakistan: A comparative assessment of the role played by perceptions. Business Review, 14(2), 13-30. Retrieved from https://doi.org/10.54784/ 1990-6587.1015

This article is brought to you by iRepository for open access under the Creative Commons Attribution 4.0 License and is available at https://ir.iba.edu.pk/businessreview/vol14/iss2/2. For more information, please contact irepository@iba.edu.pk. 


\title{
Entrepreneurship in Pakistan: A comparative assessment of the role played by perceptions
}

\author{
Talha Nadeem • Mohammad Nishat • \\ Farooq Pasha
}

\begin{abstract}
This paper conducts a preliminary assessment of how perceptions influence the decision to opt for entrepreneurship, and whether they vary across selected countries. The central focus is Pakistan: the country's outcomes are duly contrasted with results from Bangladesh, an amalgamated grouping of factordriven economies, and a broad sample of global economies. A pooled dataset of 69 countries surveyed in 2010 and 2011 by the Global Entrepreneurship Monitor is utilized. The model takes perceptual factors into account, in addition to the traditional demographic variables which dominate the literature. The results indicate that, globally, three perceptual variables namely opportunity awareness, personally knowing an entrepreneur, and self-confidence in one's own knowledge, skills and abilities increase the likelihood of a person turning into an entrepreneur; the latter two variables are also correlated with the decision to pursue entrepreneurship in Pakistan. However, there are differences in the impact of other perceptual variables like opportunity awareness and fear of failure and also among some standard demographic variables across the set of countries which constitute the research.
\end{abstract}

Keywords Perceptual variables · Entrepreneurship - Factor-driven economies.

Talha Nadeem

Economic Policy Review Department, State Bank of Pakistan

E-mail: talha.nadeem@sbp.org.pk

Mohammad Nishat

Institute of Business Administration, Karachi

Farooq Pasha

Research Department, State Bank of Pakistan

Disclaimer: The opinions, findings and recommendations expressed in this paper are strictly those of the authors. They do not reflect the views of the State Bank of Pakistan. The authors are responsible for any errors or omissions and the State Bank of Pakistan does not take any responsibility for the correctness of the paper. 


\section{Introduction}

Of late, there has been an explosion of interest in entrepreneurship globally in the backdrop of events like the financial crisis of 2008 and the pressing need to counter unemployment pressures. Rasool et al (2012) find that policy makers have increasingly laid more emphasis on entrepreneurship as a means of promoting growth. If such growth leads to significant job creation, then a plausible consequence is a reduction in prevailing unemployment. According to Haque et al (2007), rising entrepreneurial activity tends to occur in tandem with higher growth rates, which in turn creates more opportunities to find employment.

For developing countries like Pakistan, however, one of the constraints that limited research on entrepreneurship until recently was the limited amount of comparable data across countries and regions. Specifically, researchers in the country could conduct limited studies pertaining to entrepreneurship in the country by utilizing a data set like the Pakistan Labor Force Survey. However, nationally representative surveys available in the country were not designed with an express focus on entrepreneurship, and therefore lacked the richness and detail required for a comprehensive study. In the global context, the advent of the Global Entrepreneurship Monitor (GEM) in 1999 was a positive step taken to tackle such constraints, since the surveys utilized a standardized questionnaire tailored to entrepreneurship research, which could collect comparable information across countries. Despite its limitations ${ }^{1}$, the GEM Adult Population Survey opened up new possibilities of cross-country research to enrich our understanding of entrepreneurs, and by extension lead to better, informed policy-making. Pakistan participated in the GEM surveys for the first time in 2010, followed by 2011 and 2012 respectively.

This paper aims to develop a better understanding of entrepreneurial decisionmaking, by gauging the relative importance of perceptual and demographic factors in the decision to pursue entrepreneurship. Essentially, we develop comparative profiles of entrepreneurial decision-making in Pakistan, vis-a-vis other countries at similar and dissimilar levels of economic development. The ultimate goal is to provide policy-makers and stakeholders with actionable information. For example, universities offering programs and courses on entrepreneurship might benefit from knowing which attitudinal variables are particularly important, and subsequently test their graduates to ascertain whether the university's intervention was successful in fostering the desired mindset.

The paper proceeds as follows: section 2 reviews the relevant literature to form a case for the inclusion of variables in the model, proposing a tentative hypothesis corresponding to each variable; section 3 discusses the data and model utilized; section 4 discusses the empirical results; section 5 touches upon learning and policy implications; and finally, section 6 offers concluding remarks.

\footnotetext{
1 Only 10 countries participated in the 1999 surveys and any given country was not guaranteed to participate each year, leaving gaps in the time series
} 


\section{Literature review and hypothesis development}

Prior studies suggest that the ability to perceive opportunities to do business in a given environment influence the decision-making process of a potential entrepreneur (Eckhart and Shane 2003; Shane 2000). Specifically, information asymmetry can create varying beliefs regarding the viability of doing business, and opportunity perception is a prerequisite to opportunity exploitation. Thus, the following hypothesis. Hypothesis 1: Individuals who readily perceive opportunities to do business in the near future are more likely to become entrepreneurs compared to those individuals who are unaware or dismissive of such opportunities

With regard to networks, there is evidence to suggest that those individuals who have a diverse set of ties with members of the larger community have an edge in initiating new ventures (Aldrich and Martinez 2007; Backman and Karlsson 2013). Strong ties, characterized by trust and emotional closeness, are especially useful, and the entrepreneur can use these connections to have access to a wide range of knowledge, expertise and resources. This motivates our next hypothesis. Hypothesis 2: Those individuals who personally know someone who started a business in the past two years are more likely to turn entrepreneur themselves, compared to those individuals who lack such a connection

In addition, existing literature identifies a link between self-efficacy as conceptualized by Bandura (1977) and the decision to launch and persist with a startup (Boyd and Vozikis 1994; Markman et al 2002). Individuals who are convinced that they possess the knowledge and aptitude to undertake a task tend to take on activities more readily than those who lack conviction in their own abilities (Bosma et al 2000). Hence, we surmise that, Hypothesis 3: Individuals who declare that they possess the knowledge, skills and aptitude required to start a new business are likelier to actually do so compared to individuals who lack this faith in themselves.

The impact of a fear of failure on entrepreneurial pursuits has also been previously documented. Fear of failure tends to reduce the likelihood that a person will launch a new venture (Arenius and Minniti 2005; Wagner and Sternberg 2004). This self-identified fear of failure can also be taken as a proxy measure for risk aversion, or in other words, the individual's lack of appetite for risk-taking behavior. The next hypothesis captures this dimension. Hypothesis 4: Individuals who acknowledge that fear of failure would prevent them from starting a business are indeed less likely to take the entrepreneurial route compared to those individuals who disregard this fear

Moreover, women have been found to be held back to a greater degree by perceptual factors as compared to men in the decision to start their own business (Koellinger et al 2013; Langowitz and Minniti 2007). Thus, our next hypothesis. Hypothesis 5: Gender has a significant impact on the decision to pursue entrepreneurship, with women in general being less inclined to do so than men.

Furthermore, Backes-Gellner and Moog (2013) analyzed survey data from a sample of 2,000 German students and concluded that obtaining higher levels of education may actually reduce the disposition to pursue entrepreneurship, since specialists are more likely to be successful employees, whereas those with 
a balance of human and social skills are more likely to become successful entrepreneurs. By contrast, Poschke (2013) asserts that the least and the most able individuals, in terms of schooling, are likelier to become entrepreneurs and persist with their choice; this is due to low opportunity cost on the former extreme, and high potential returns stemming from greater ability and productivity on the latter extreme. This leads to the next hypothesis. Hypothesis 6 : The least and most educated individuals are more likely to engage in entrepreneurship, compared to individuals who have a few years of schooling.

Another explanatory variable of entrepreneurial choice proposed in the existing literature is the optimism of entrepreneurs (Cooper et al 1988; Shane 2000), which is inextricably linked to age. This hypothesis is backed by analysis by Fraser and Greene (2006) of British Social Attitudes Surveys from 198499, which indicated that entrepreneurs are, on average, more optimistic than employees, while this optimism declines with experience. Thus Hypothesis 7: Younger individuals are more likely to take the entrepreneurial route compared to older counterparts.

An additional factor of relevance is the initial wealth or capital possessed by would-be entrepreneurs (Praag and Ophem 1995). Evans and Jovanovic (1989) estimate that entrepreneurs are in most cases limited to using less than 1.5 times their wealth in order to finance their ventures. An important corollary is that wealthier individuals may be more predisposed to choose entrepreneurship over paid employment, since they may be less risk-averse (Kihlstrom and Laffont 1979). While the GEM dataset does not explicitly ask respondents about their wealth as individuals, it does contain data on household income. Taking this as a loose proxy for wealth, we propose this hypothesis. Hypothesis 8: Individuals belonging to households which constitute the top one-third of the income distribution in a given country are more likely to launch a startup compared to individuals associated with lower-income households.

Finally, prior research suggests that having the safety net of paid employment increases the likelihood of an individual starting a new venture (Arenius and Minniti 2005; Taylor 1996), leading to our last hypothesis. Hypothesis 9: Individuals who are engaged in full-time or part-time paid work are more likely to take the entrepreneurial route.

\section{Data and econometric model}

\subsection{Data}

We combine data of GEM Adult Population Surveys (APS) for 2010 and 2011 to arrive at a pooled sample of 69 countries $^{2}$. The pooled dataset combines observations from 59 countries surveyed in 2010, and 52 countries surveyed in 2011. While majority of countries participated in surveys for both years, some countries participated in only one year, either 2010 or 2011 . Hence, the pooling approach allows us to expand the sample of countries utilized for this research.

\footnotetext{
2 Raw data utilized in this study is available in the GEM repository: http://www.gemconsortium.org/data/sets?id=aps
} 
The pooled dataset has 307, 268 observations in total (country-wise breakup is given in the Appendix). Individuals lying within the age bracket of 18-64 years were surveyed in each country using a standardized questionnaire with the aim of gathering data from a representative sample of workforce.

Furthermore, GEM's primary country groupings are derived from classifications found in the World Economic Forum's Global Competitiveness Report. Factor-driven economies tend to rely greatly on labor and natural resources, with subsistence agriculture and extraction businesses predominating. Efficiency-driven economies are characterized by industrialization, economies of scale and large capital intensive setups. Finally, innovation-driven economies are knowledge-intensive with vibrant service sectors. Table 1 contains a description of the key variables utilized.

\subsection{Model}

From an overview of existing studies of entrepreneurship based on GEM data and given the presence of a limited dependent/binary outcome dependent variable, the probit or logistic regression is well-suited to the analysis. This research utilizes the probit framework ${ }^{3}$. We use nascent entrepreneurs as our dependent variable, namely those individuals who are actively involved in starting a new venture. The first question which probed into nascent entrepreneurship status was: (1a.) Are you, alone or with other, currently trying to start a new business, including any self-employment or selling any goods or services to others? Affirmative responses were followed up by two more questions: (2a.) Over the past twelve months have you done anything to help start this new business, such as looking for equipment or a location, organizing a start-up team, working on a business plan, beginning to save money, or any other activity that would help launch a business? (2b.) Will you personally own all, part or none of this business? Those who said yes to question (2a.) and all or part to (2b.) were identified to be nascent entrepreneurs.

The following probit model is duly specified:

$$
\begin{aligned}
\text { Nascent }_{i}= & \gamma_{0}+\gamma_{1} \text { Age }_{i}+\gamma_{2} \text { Agesqr }_{i}+\gamma_{3} \text { women }_{i}+\gamma_{4} \text { Educ }_{i}+ \\
& \gamma_{5} \text { work }_{i}+\gamma_{6} \text { hhinc }_{i}+\gamma_{7} \text { opport }_{i}+\gamma_{8} \text { knoent }_{i}+ \\
\gamma_{9} \text { skill }_{i}+ & \gamma_{10} \text { goodchc }_{i}+\gamma_{11} \text { media }_{i}+\gamma_{12} \text { frfail }_{i}+\gamma_{10} \text { region }_{\text {econ }} \text { cls }
\end{aligned}
$$

\section{Empirical results and discussion}

Table 2 presents the correlation matrix for shortlisted variables. At the $5 \%$ significance level (indicated by asterisks), all of the variables are found to be significantly correlated with nascent entrepreneurship. The table provides support for inclusion of perceptual variables, with the ability to identify new venture opportunities, personally knowing other entrepreneurs, and possessing the

\footnotetext{
${ }^{3}$ Empirically, there tends to be "little difference between the predicted probabilities from probit and logit models. The difference is greatest in the tails where probabilities are close to 0 or 1" (Cameron and Trivedi 2005)
} 
T. Nadeem et al

Table 1: Description of variables

\begin{tabular}{|c|c|c|c|}
\hline Variable & Code & Expected sign & Description \\
\hline $\begin{array}{l}\text { Nascent en- } \\
\text { trepreneurs }\end{array}$ & nascent & $\begin{array}{l}\text { (dependent vari- } \\
\text { able) }\end{array}$ & $\begin{array}{l}\text { Dummy variable (two categories). Coded ' } 1 \text { ' for indi- } \\
\text { viduals in 18-64 age group who are actively involved } \\
\text { in setting up a business, which they will either own or } \\
\text { co-own; in addition, the business has not paid salaries } \\
\text { etc. to owners for }>3 \text { months. Coded ' } 0 \text { ' otherwise }\end{array}$ \\
\hline Age & Age & + & $\begin{array}{l}\text { Respondent's age. Acts as a proxy for optimism, } \\
\text { which is theoretically higher among younger, less ex- } \\
\text { perienced individuals }\end{array}$ \\
\hline Age squared & Agesqr & - & $\begin{array}{l}\text { Squared values of Age. Captures quadratic (non- } \\
\text { linear) effect, if any }\end{array}$ \\
\hline Women & women & - & Dummy variable. Equals 1 if female, 0 otherwise \\
\hline Education & educ & $\begin{array}{l}+ \text { for least and } \\
\text { most educated }\end{array}$ & $\begin{array}{l}\text { Five categories: no education, some secondary educa- } \\
\text { tion, secondary degree (base), post-secondary educa- } \\
\text { tion, \& graduate degree }\end{array}$ \\
\hline Work status & work & $\begin{array}{l}+ \text { for "full or part } \\
\text { time" }\end{array}$ & $\begin{array}{l}\text { Three categories: "full or part-time workers" (base), } \\
\text { "not working", \& "retired or student" }\end{array}$ \\
\hline $\begin{array}{l}\text { Household } \\
\text { income }\end{array}$ & hhinc & + for upper third & $\begin{array}{l}\text { Three groups: upper, middle (base) or lower third of } \\
\text { income distribution, of country of origin. Acts as a } \\
\text { proxy for wealth }\end{array}$ \\
\hline $\begin{array}{l}\text { Opportunity } \\
\text { perception }\end{array}$ & opport2 & + & $\begin{array}{l}\text { Yes/no response to question, "In the next six months, } \\
\text { will there be good opportunities for starting a busi- } \\
\text { ness in the area where you live?" }\end{array}$ \\
\hline $\begin{array}{l}\text { Knowing } \\
\text { other en- } \\
\text { trepreneurs }\end{array}$ & knoent2 & + & $\begin{array}{l}\text { Yes/no response to question, "Do you know some- } \\
\text { one personally who started a business in the past } 2 \\
\text { years?" Acts as a proxy for networks }\end{array}$ \\
\hline $\begin{array}{l}\text { Confidence } \\
\text { in one's own } \\
\text { skills }\end{array}$ & skill & + & $\begin{array}{l}\text { Yes/no response to question. "Do you have the knowl- } \\
\text { edge, skill and experience required to start a new busi- } \\
\text { ness?" }\end{array}$ \\
\hline $\begin{array}{l}\text { Fear of fail- } \\
\text { ure }\end{array}$ & frfail & - & $\begin{array}{l}\text { Yes/no response to question, "Would fear of failure } \\
\text { prevent you from starting a business?" Acts as a } \\
\text { proxy for risk-averseness }\end{array}$ \\
\hline Good choice & goodchc & + & $\begin{array}{l}\text { Yes/no response to statement, "In your country, most } \\
\text { people consider starting a new business a desirable } \\
\text { career choice" }\end{array}$ \\
\hline $\begin{array}{l}\text { Media cover- } \\
\text { age }\end{array}$ & media & + & $\begin{array}{l}\text { Yes/no response to statement, "In your country, you } \\
\text { will often see stories in the public media about suc- } \\
\text { cessful new businesses" }\end{array}$ \\
\hline $\begin{array}{l}\text { Economic } \\
\text { classification }\end{array}$ & econ_cls & $\begin{array}{l}+ \text { for factor- } \\
\text { driven }\end{array}$ & $\begin{array}{l}\text { Countries grouped by economic classification. Three } \\
\text { main groups: factor-driven, efficiency-driven, and } \\
\text { innovation-driven (base). (Transition economies } \\
\text { treated separately; details available in Appendix, } \\
\text { Table A3) }\end{array}$ \\
\hline $\begin{array}{l}\text { Regional } \\
\text { classification }\end{array}$ & region & $\begin{array}{l}+\quad \text { for } \begin{array}{r}\text { Sub- } \\
\text { Saharan } \\
\text { MENASA }\end{array}\end{array}$ & $\begin{array}{l}\text { Countries grouped by region. Six groups: Sub- } \\
\text { Saharan Africa, MENASA, Latin America and } \\
\text { Caribbean, Eastern Europe, Asia Pacific, United } \\
\text { States and Western Europe (base). }\end{array}$ \\
\hline
\end{tabular}

knowledge skills and abilities required to start a business being the perceptual factors which increase the likelihood of turning entrepreneur, and the fear of failure having the opposite impact, in line with a priori expectation. Similarly, there is an indication that older individuals and women are less likely to opt for entrepreneurship, while household income is positively correlated with startup activity. 
Meanwhile, table 3 provides coefficients, marginal effects and select summary statistics for four alternate model specifications using the global pooled sample only. We begin with the global specification as a sort of baseline reflecting the nature of entrepreneurial decision-making in general against which we subsequently compare country differences for Pakistan and Bangladesh, as well as the differences due to level of economic development, on average. Model 1 is limited to demographic variables only; Model 2 adds perceptual variables to the mix; Model 3 introduces a regional dummy; and Model 4 utilizes a dummy reflecting level of economic development. Overall, the summary statistics at the bottom of the table indicate that Model 3 and Model 4 have similar explanatory power, with pseudo R-squared of 0.138 and $0.137^{4}$. Beginning with perceptual variables, the marginal effects of models $3 \mathrm{~g}$ and $4 \mathrm{~g}$ indicate that those individuals who readily perceive opportunities to do business in the near future are, on average, $3 \%$ more likely to become entrepreneurs compared to those who lack this orientation. This finding lends support to Hypothesis 1 for the global sample.

Similarly, personally knowing an entrepreneur who started a business in the past two years also increases the likelihood of starting one's own venture by around 3\%, while self-confidence in one's own knowledge, skills and ability to run a business nudges the probability by 5.7 to $5.8 \%$, with reference to marginal effects $M f x_{3 g}$ and $M f x_{4 g}$; thus, Hypotheses 2 and 3 are also backed up by empirical findings. Hypothesis 4 also holds for the data, with individuals who cite fear of failure as an inhibiting factor being 1.5 to $1.8 \%$ less likely to pursue entrepreneurship compared to individuals who declare that such fear would not hold them back.

In terms of more standard demographic variables, entrepreneurship appears to be more of a man's game, with women being $1 \%$ less likely on average to go for entrepreneurship, given the marginal effects observed across all four specifications. This finding leads us to accept Hypothesis 5 for the global sample.

In terms of education, once we account for level of economic development by introducing factor-driven/efficiency-driven/innovation-driven dummy in Model 4, the marginal effect $M f x_{4 g}$ indicates that those with no education are slightly less likely $(-0.46 \%)$ to pursue entrepreneurship compared to those who possess a secondary degree, while those with graduate degrees are $0.83 \%$ more likely to do so. However, if we choose to employ regional dummy rather than economic development dummy, the marginal effect of 'no education' becomes insignificant. So while the results for education are sensitive to the specification, we fail to find support from this data of a U-shaped relationship between years of schooling and entrepreneurial tendency, and thus we fail to accept Hypothesis 6 for the global sample.

\footnotetext{
4 According to McFadden et al (1977), a pseudo R-squared of 0.2 to 0.4 represents an excellent fit. So we deduce that introducing perceptual variables in Model $2 \mathrm{~g}$ significantly improves the goodness of fit compared to Model $1 \mathrm{~g}$, and accounting for either the level of economic development or geographical regions as in Models $3 \mathrm{~g}$ and $4 \mathrm{~g}$ gives us a specification with moderately good fit.
}

Business Review: (2019) 14(2):13-30 


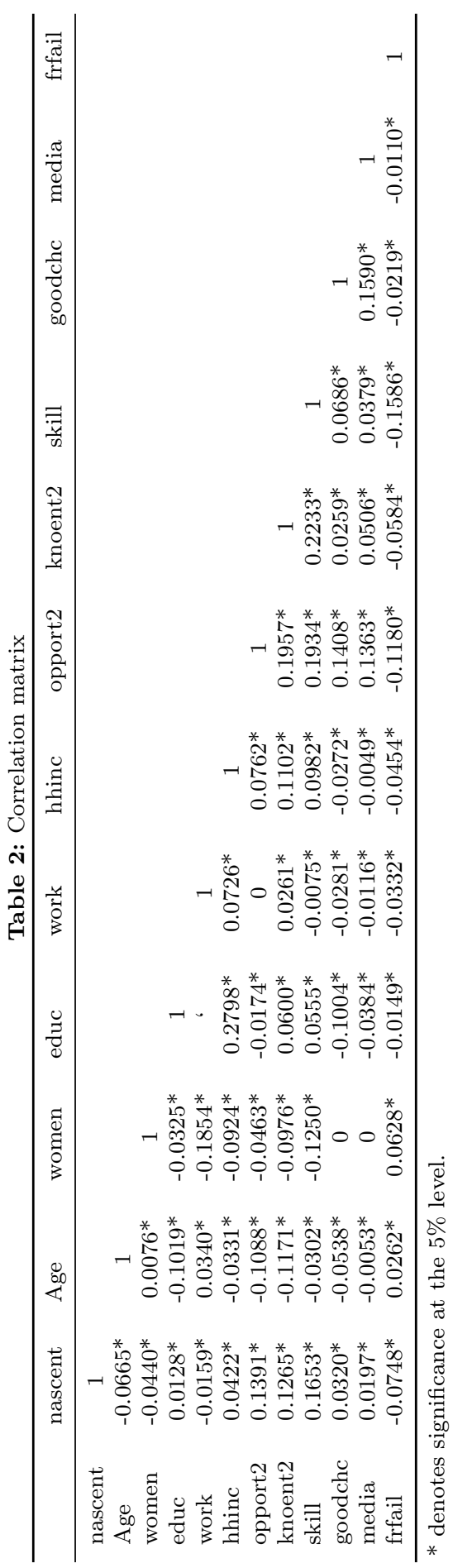

20
Business Review: (2019) 14(2):13-30 
Entrepreneurship in Pakistan...

Table 3: Coefficients and marginal effects for global pooled sample

\begin{tabular}{|c|c|c|c|c|c|c|c|c|}
\hline & $\begin{array}{r}\text { (1) } \\
\text { Mode1_1g }\end{array}$ & $\begin{array}{r}(2) \\
\operatorname{Mfx} x_{-} 19\end{array}$ & $\begin{array}{r}\text { (3) } \\
\text { Mode1_2g }\end{array}$ & $\begin{array}{r}(4) \\
\operatorname{Mfx}_{-} 2 g\end{array}$ & $\begin{array}{r}\text { (5) } \\
\text { Mode1_39 }\end{array}$ & $\begin{array}{r}(6) \\
\operatorname{MfX}_{3} 39\end{array}$ & $\begin{array}{r}\text { (7) } \\
\text { Mode1_49 }\end{array}$ & $\begin{array}{r}(8) \\
\operatorname{MfX}_{-} 4 \mathrm{~g}\end{array}$ \\
\hline \multicolumn{9}{|l|}{ in } \\
\hline Age & $\begin{array}{l}0.00829 * \star \star \\
(0.001)\end{array}$ & $\begin{array}{l}0.00095^{\star \star \star \star} \\
(0.001)\end{array}$ & $\begin{array}{l}0.01130 * \star \star \\
(0.000)\end{array}$ & $\begin{array}{l}0.00131 * \star \star \\
(0.000)\end{array}$ & $\begin{array}{l}0.01828 * * * \\
(0.000)\end{array}$ & $\begin{array}{l}0.00207 * * * \\
(0.000)\end{array}$ & $\begin{array}{l}0.01696 * \star \star \\
(0.000)\end{array}$ & $\begin{array}{l}0.00192 * * * \\
(0.000)\end{array}$ \\
\hline Age squared & $\begin{array}{l}-0.00025 * \star \star \\
(0.000)\end{array}$ & $\begin{array}{l}-0.00003^{* \star \star} \\
(0.000)\end{array}$ & $\begin{array}{l}-0.00026^{\star \star \star} \\
(0.000)\end{array}$ & $\begin{array}{l}-0.00003^{* \star \star} \\
(0.000)\end{array}$ & $\begin{array}{l}-0.00032 \star \star \star \\
(0.000)\end{array}$ & $\begin{array}{l}-0.00004 * \star \star \\
(0.000)\end{array}$ & $\begin{array}{l}-0.00030 \star \star \star \\
(0.000)\end{array}$ & $\begin{array}{l}-0.00003 * \star \star \\
(0.000)\end{array}$ \\
\hline Women=1 & $\begin{array}{c}-0.14667 * \star \star \\
(0.000)\end{array}$ & $\begin{array}{c}-0.01677^{\star \star \star} \\
(0.000)\end{array}$ & $\begin{array}{c}-0.05748^{\star \star \star *} \\
(0.000)\end{array}$ & $\begin{array}{c}-0.00664^{\star \star \star \star} \\
(0.000)\end{array}$ & $\begin{array}{c}-0.09322 * \star * \\
(0.000)\end{array}$ & $\begin{array}{c}-0.01049 * \star \star \\
(0.000)\end{array}$ & $\begin{array}{c}-0.07250 \star \star \star \\
(0.000)\end{array}$ & $\begin{array}{c}-0.00818 \text { *** } \\
(0.000)\end{array}$ \\
\hline 0 . No educ. & $\begin{array}{l}0.05771 * \star \star \\
(0.000)\end{array}$ & $\begin{array}{l}0.00708^{* \star *} \\
(0.000)\end{array}$ & $\begin{array}{l}0.06113^{\star \star \star} \\
(0.001)\end{array}$ & $\begin{array}{l}0.00755^{\star \star \star} \\
(0.001)\end{array}$ & $\begin{array}{l}0.01221 \\
(0.502)\end{array}$ & $\begin{array}{l}0.00138 \\
(0.503)\end{array}$ & $\begin{array}{c}-0.04146^{*} \\
(0.024)\end{array}$ & $\begin{array}{c}-0.00461 * \\
(0.022)\end{array}$ \\
\hline 1. Some 2 ndry & $\begin{array}{c}-0.05343^{* \star \star} \\
(0.000)\end{array}$ & $\begin{array}{c}-0.00602 * * * \\
(0.000)\end{array}$ & $\begin{array}{c}-0.08006^{\star \star \star \star} \\
(0.000)\end{array}$ & $\begin{array}{c}-0.00902 * * \star \\
(0.000)\end{array}$ & $\begin{array}{c}-0.05863^{* * *} \\
(0.000)\end{array}$ & $\begin{array}{c}-0.00633 * * * \\
(0.000)\end{array}$ & $\begin{array}{c}-0.12257 \text { *t* } \\
(0.000)\end{array}$ & $\begin{array}{c}-0.01294 * \star \star \star \\
(0.000)\end{array}$ \\
\hline 3. Post 2 ndry & $\begin{array}{c}-0.03272^{\star \star} \\
(0.001)\end{array}$ & $\begin{array}{c}-0.00375^{\star \star} \\
(0.001)\end{array}$ & $\begin{array}{c}-0.03462^{\star \star *} \\
(0.006)\end{array}$ & $\begin{array}{c}-0.00402^{\star \star} \\
(0.006)\end{array}$ & $\begin{array}{l}0.02960 * \\
(0.022)\end{array}$ & $\begin{array}{l}0.00339 \star \\
(0.022)\end{array}$ & $\begin{array}{l}0.04086^{\star \star} \\
(0.002)\end{array}$ & $\begin{array}{l}0.00479 \star \star \\
(0.002)\end{array}$ \\
\hline 4. Grad. degree & $\begin{array}{c}-0.04148 * \\
(0.027)\end{array}$ & $\begin{array}{c}-0.00472 * \\
(0.024)\end{array}$ & $\begin{array}{r}-0.02919 \\
(0.213)\end{array}$ & $\begin{array}{r}-0.00340 \\
(0.207)\end{array}$ & $\begin{array}{l}0.07317 * * \\
(0.002)\end{array}$ & $\begin{array}{l}0.00861 * * \\
(0.003)\end{array}$ & $\begin{array}{l}0.06973 * \star \\
(0.004)\end{array}$ & $\begin{array}{l}0.00833 * \star \\
(0.005)\end{array}$ \\
\hline o. Not working & $\begin{array}{c}-0.11796^{* \star *} \\
(0.000)\end{array}$ & $\begin{array}{c}-0.01374 * * * \\
(0.000)\end{array}$ & $\begin{array}{c}-0.07248^{* \star *} \\
(0.000)\end{array}$ & $\begin{array}{c}-0.00854^{* \star *} \\
(0.000)\end{array}$ & $\begin{array}{c}-0.07691 * * * \\
(0.000)\end{array}$ & $\begin{array}{c}-0.00881 * * * \\
(0.000)\end{array}$ & $\begin{array}{c}-0.12647 * \star * * \\
(0.000)\end{array}$ & $\begin{array}{c}-0.01428 * * * \\
(0.000)\end{array}$ \\
\hline 2. Ret | Stud & $\begin{array}{l}-0.43592 * \star \star \\
(0.000)\end{array}$ & $\begin{array}{l}-0.03984 * \star \star \\
(0.000)\end{array}$ & $\begin{array}{l}-0.36141 * \star \star \\
(0.000)\end{array}$ & $\begin{array}{l}-0.03507 * \star \star \\
(0.000)\end{array}$ & $\begin{array}{l}-0.35202 \star \star \star \star \\
(0.000)\end{array}$ & $\begin{array}{l}-0.03368 * \star * \\
(0.000)\end{array}$ & $\begin{array}{c}-0.36321 \star \star \star \\
(0.000)\end{array}$ & $\begin{array}{l}-0.03512 \star \star \star \\
(0.000)\end{array}$ \\
\hline 1. Low 338ile & $\begin{array}{c}-0.07044^{\star \star \star} \\
(0.000)\end{array}$ & $\begin{array}{c}-0.00732 * \star \star \\
(0.000)\end{array}$ & $\begin{array}{c}-0.00879 \\
(0.587)\end{array}$ & $\begin{array}{r}-0.00099 \\
(0.586)\end{array}$ & $\begin{array}{l}0.03600 \star \\
(0.029)\end{array}$ & $\begin{array}{l}0.00400 * \\
(0.030)\end{array}$ & $\begin{array}{l}0.04895 * \star \\
(0.003)\end{array}$ & $\begin{array}{l}0.00550 * \star \\
(0.003)\end{array}$ \\
\hline 3. Upp. 338ile & $\begin{array}{l}0.08493^{* \star \star} \\
(0.000)\end{array}$ & $\begin{array}{l}0.00995 * \star \star \\
(0.000)\end{array}$ & $\begin{array}{l}0.04068 * \star \star \\
(0.000)\end{array}$ & $\begin{array}{l}0.00472 \star \star \star \\
(0.000)\end{array}$ & $\begin{array}{l}0.05225^{* \star \star} \\
(0.000)\end{array}$ & $\begin{array}{l}0.00586 * \star * \\
(0.000)\end{array}$ & $\begin{array}{l}0.04655 \star \star \star \\
(0.000)\end{array}$ & $\begin{array}{l}0.00522 \star \star \star \\
(0.000)\end{array}$ \\
\hline Opportunity $=1$ & & & $\begin{array}{l}0.37507 * * * \\
(0.000)\end{array}$ & $\begin{array}{l}0.04313^{* \star *} \\
(0.000)\end{array}$ & $\begin{array}{l}0.28362 \star \star \star \\
(0.000)\end{array}$ & $\begin{array}{l}0.03172 * * * \\
(0.000)\end{array}$ & $\begin{array}{l}0.30810 * \star \star \\
(0.000)\end{array}$ & $\begin{array}{l}0.03451 \star \star \star \\
(0.000)\end{array}$ \\
\hline Know entrep $=1$ & & & $\begin{array}{l}0.28791 * \star \star * \\
(0.000)\end{array}$ & $\begin{array}{l}0.03345^{* \star *} \\
(0.000)\end{array}$ & $\begin{array}{l}0.30212^{\star \star *} \\
(0.000)\end{array}$ & $\begin{array}{l}0.03424 * * * \\
(0.000)\end{array}$ & $\begin{array}{l}0.26464 * \star \star * \\
(0.000)\end{array}$ & $\begin{array}{l}0.03000 * * * \\
(0.000)\end{array}$ \\
\hline s.UP skill=1 & & & $\begin{array}{l}0.60856^{\star \star \star} \\
(0.000)\end{array}$ & $\begin{array}{l}0.06190 * \star \star \\
(0.000)\end{array}$ & $\begin{array}{l}0.56852 \star \star \star \\
(0.000)\end{array}$ & $\begin{array}{l}0.05677^{* \star \star \star} \\
(0.000)\end{array}$ & $\begin{array}{l}0.58444 * \star \star \\
(0.000)\end{array}$ & $\begin{array}{l}0.05828 * \star \star \\
(0.000)\end{array}$ \\
\hline Good choice $=1$ & & & $\begin{array}{l}0.03898 * \star \star \\
(0.001)\end{array}$ & $\begin{array}{l}0.00446^{\star \star \star} \\
(0.001)\end{array}$ & $\begin{array}{c}-0.02647 * \\
(0.030)\end{array}$ & $\begin{array}{c}-0.00301 * \\
(0.031)\end{array}$ & $\begin{array}{r}-0.01060 \\
(0.381)\end{array}$ & $\begin{array}{r}-0.00120 \\
(0.383)\end{array}$ \\
\hline Media image $=1$ & & & $\begin{array}{r}-0.01237 \\
(0.245)\end{array}$ & $\begin{array}{r}-0.00144 \\
(0.246)\end{array}$ & $\begin{array}{c}-0.03033^{* *} \\
(0.006)\end{array}$ & $\begin{array}{c}-0.00344 * * \\
(0.006)\end{array}$ & $\begin{array}{c}-0.02848 * \star \\
(0.009)\end{array}$ & $\begin{array}{c}-0.00324 * \star \\
(0.009)\end{array}$ \\
\hline Fear fail. $=1$ & & & $\begin{array}{c}-0.17648 * \star \star \\
(0.000)\end{array}$ & $\begin{array}{c}-0.01969 * \star \star \\
(0.000)\end{array}$ & $\begin{array}{c}-0.13355 * \star \star \\
(0.000)\end{array}$ & $\begin{array}{l}-0.01467 * \star \star \\
(0.000)\end{array}$ & $\begin{array}{c}-0.16029 * \star \star \\
(0.000)\end{array}$ & $\begin{array}{c}-0.01754 \text { *** } \\
(0.000)\end{array}$ \\
\hline 1. MENASA & & & & & $\begin{array}{l}0.17136 * \star \star \\
(0.000)\end{array}$ & $\begin{array}{l}0.01390 * \star \star \\
(0.000)\end{array}$ & & \\
\hline 2. OAfrica & & & & & $\begin{array}{l}0.44149 * * * \\
(0.000)\end{array}$ & $\begin{array}{l}0.04428 * \star \star \\
(0.000)\end{array}$ & & \\
\hline 3. $L A m+C r b$ & & & & & $\begin{array}{l}0.58487^{* \star \star} \\
(0.000)\end{array}$ & $\begin{array}{l}0.06529 * * * \\
(0.000)\end{array}$ & & \\
\hline 4. E Europe & & & & & $\begin{array}{l}0.18924 \star \star \star \\
(0.000)\end{array}$ & $\begin{array}{l}0.01558 * \star \star \\
(0.000)\end{array}$ & & \\
\hline 5. Asia Pac & & & & & $\begin{array}{l}0.28406^{\star \star \star} \\
(0.000)\end{array}$ & $\begin{array}{l}0.02522 * \star \star \\
(0.000)\end{array}$ & & \\
\hline 1. Factr-drv & & & & & & & $\begin{array}{l}0.69231 * \star \star \\
(0.000)\end{array}$ & $\begin{array}{l}0.08217 * \star \star \\
(0.000)\end{array}$ \\
\hline 2. Transt1_2 & & & & & & & $\begin{array}{l}0.31715 * \star \star \\
(0.000)\end{array}$ & $\begin{array}{l}0.02842 \star \star \star \star \\
(0.000)\end{array}$ \\
\hline 3. Effic-drv & & & & & & & $\begin{array}{l}0.51380 * \star \star \\
(0.000)\end{array}$ & $\begin{array}{l}0.05355^{\star \star \star} \\
(0.000)\end{array}$ \\
\hline 4. Transt $2{ }^{3}$ & & & & & & & $\begin{array}{l}0.39283 * \star \star \\
(0.000)\end{array}$ & $\begin{array}{l}0.03734 * \star \star \\
(0.000)\end{array}$ \\
\hline Observation & 23982 & 239825 & 167172 & 167172 & 167172 & 167172 & 167172 & 167172 \\
\hline Pseudo R-squarec & 0.028 & & 0.116 & & 0.138 & & 0.137 & \\
\hline Chi-squared & 3030.33853 & & 9487.29440 & & 11329.85 & 5197 & 11230 & 0.26080 \\
\hline Log LI-hd & -52306.02936 & & -36260.3 & 35864 & & 339.07985 & & -35388.87544 \\
\hline CC proport. & 94.09236 & & 93.32005 & & 93.32005 & & 93.32005 & \\
\hline
\end{tabular}

In addition, we find a quadratic (non-linear) relationship between age and nascent entrepreneurship across all four specifications, since the marginal effects $\left(M f x_{1 g}\right.$ to $\left.M f x_{4 g}\right)$ of Age are positive while the marginal effects of Age squared are negative ${ }^{5}$. In a nutshell, the expectation that entrepreneurship is a young person's game, as embodied by Hypothesis 7, is confirmed.

Considering household income, individuals belonging to households in the lower and upper third of the income distribution within each country have a

\footnotetext{
5 In other words, initially (from 18 years upwards) the older a person is, the likelier they are to engage in entrepreneurship. However, this trend tends to reach a peak and then reverse trajectory.
}

Business Review: (2019) 14(2):13-30 
greater likelihood of pursuing entrepreneurship compared to those in the middle $33 \%$ (the base), with respect to $M f x_{3 g}$ and $M f x_{4 g}$. This refutes the anticipated effect from Hypothesis 8 .

We also find evidence in favor of Hypothesis 9 that individuals engaged in full or part time work are more likely to become entrepreneurs compared to individuals who are currently not working or are classified as students and retired individuals. Taking marginal effects of models 3 and 4 into consideration, retirees and students are around $3.5 \%$ less likely to be entrepreneurs compared to working individuals (the base category), while the marginal effect is around $1 \%$ for individuals who are not involved in work.

Moreover, Model 3 helps identify that individuals belonging to country group US and Western Europe' (taken as base category) are least inclined to be nascent entrepreneurs. By contrast, individuals from Latin America and Caribbean country group are $6.5 \%$ more inclined towards entrepreneurship, while individuals from Middle East, North Africa and South Asia (MENASA) are 1.3\% more likely to be nascent entrepreneurs compared to the base, and so on.

Finally, Model 4 with its economic development dummy indicates that individuals from innovation driven economies (base category) are least inclined to be nascent entrepreneurs. By contrast, individuals belonging to factor-driven economies are $8.2 \%$ more likely to be nascent entrepreneurs.

Next, we analyze a comparative table (table 4) to contrast some of the key results for demographic and perceptual independent variables between: a) the global sample, b) the Pakistan sub-sample, c) the Bangladesh sub-sample, and d) the factor-driven economies sub-sample. Essentially, the first two columns of table 4 are exactly the same as the third and fourth columns of table 3 , and contain coefficients $\left(M_{o d e l_{2 g}}\right)$ and marginal effects $\left(M f x_{2 g}\right)$ for global specification $2 \mathrm{~g}$, which contains both demographic and perceptual variables. Meanwhile, columns three and four of table 4 provide results from the Pakistani sub-sample in isolation, columns five and six contain similar results for neighboring Bangladesh, and columns seven and eight contain coefficients and marginal effects for factor-driven economies as a whole, excluding Pakistan. The idea (in table 4) is to identify similarities and differences between Pakistan and the world in general, Pakistan and Bangladesh-since the two countries belong to the same region (South Asia) and are similar in terms of economic developmentand finally, Pakistan vs. factor-driven economies as a whole.

Beginning with perceptual variables once again, we recall accepting Hypothesis 1 for the global sample, that individuals with greater opportunity awareness and recognition are more likely to pursue entrepreneurship, and this relationship and its estimated $4 \%$ marginal effect remains consistent for the sub-sample of factor-driven economies as a whole. On the other hand, opportunity recognition is not a statistically significant variable factor in the case of either Pakistan or Bangladesh. So we fail to accept Hypothesis 1 for these two sub-samples. Personally knowing other entrepreneurs who started a business in the past two years is, however, more or less as significant for Pakistan as it is for factor-driven economies and entrepreneurs across the world in general. So we accept Hypothesis 2 in general. Bangladesh, however, stands out as the exception, where this relationship is not validated by the current data. 
Table 4: Coefficients and marginal effects for global, Pakistani, Bangladesh and 'factor-driven' sub-samples

\begin{tabular}{|c|c|c|c|c|c|c|c|c|}
\hline & $\begin{array}{r}(1) \\
\text { Mode1_2g }\end{array}$ & $\begin{array}{r}(2) \\
\text { Mfx_L }_{-} 2 g\end{array}$ & $\begin{array}{r}\text { (3) } \\
\text { Mode1_2p }\end{array}$ & $\begin{array}{r}(4) \\
\operatorname{Mfx}_{2} 2 \mathrm{P}\end{array}$ & $\begin{array}{r}\text { (5) } \\
\text { Mode1_2b }\end{array}$ & $\begin{array}{r}{ }_{\text {Mfx }}^{(6)} \\
{ }^{2} 2 \mathrm{~b}\end{array}$ & $\begin{array}{r}\text { (7) } \\
\text { Mode1_2f }\end{array}$ & $\begin{array}{l}(8) \\
\operatorname{Mfx}_{-} 2 \mathrm{f}\end{array}$ \\
\hline \multicolumn{9}{|l|}{ main } \\
\hline Age & $\begin{array}{l}0.01130 * \star \star \\
(0.000)\end{array}$ & $\begin{array}{l}0.00131 * \star \star \\
(0.000)\end{array}$ & $\begin{array}{l}0.03762 \\
(0.110)\end{array}$ & $\begin{array}{l}0.00511 \\
(0.110)\end{array}$ & $\begin{array}{l}0.00018 \\
(0.996)\end{array}$ & $\begin{array}{l}0.00002 \\
(0.996)\end{array}$ & $\begin{array}{l}0.01856 \star \\
(0.034)\end{array}$ & $\begin{array}{l}0.00411 * \\
(0.034)\end{array}$ \\
\hline Age squared & $\begin{array}{c}-0.00026^{\star \star \star} \\
(0.000)\end{array}$ & $\begin{array}{c}-0.00003^{* \star \star} \\
(0.000)\end{array}$ & $\begin{array}{r}-0.00054 \\
(0.083)\end{array}$ & $\begin{array}{r}-0.00007 \\
(0.083)\end{array}$ & $\begin{array}{r}-0.00005 \\
(0.912)\end{array}$ & $\begin{array}{r}-0.00001 \\
(0.912)\end{array}$ & $\begin{array}{c}-0.00026^{*} \\
(0.021)\end{array}$ & $\begin{array}{c}-0.00006^{\star} \\
(0.021)\end{array}$ \\
\hline Women=1 & $\begin{array}{l}-0.05748^{* \star \star} \\
(0.000)\end{array}$ & $\begin{array}{l}-0.00664 * \star * \\
(0.000)\end{array}$ & $\begin{array}{r}-0.11044 \\
(0.339)\end{array}$ & $\begin{array}{r}-0.01459 \\
(0.324)\end{array}$ & $\begin{array}{c}-0.35227 * \\
(0.029)\end{array}$ & $\begin{array}{c}-0.03464 * \\
(0.026)\end{array}$ & $\begin{array}{l}-0.15588 * \star \star \\
(0.000)\end{array}$ & $\begin{array}{c}-0.03465 * \star \\
(0.000)\end{array}$ \\
\hline 0. No educ. & $\begin{array}{l}0.06113^{* \star \star} \\
(0.001)\end{array}$ & $\begin{array}{l}0.00755^{* \star *} \\
(0.001)\end{array}$ & $\begin{array}{c}-0.53944 * \star \star \\
(0.000)\end{array}$ & $\begin{array}{c}-0.07943^{* \star *} \\
(0.000)\end{array}$ & $\begin{array}{r}-0.27131 \\
(0.102)\end{array}$ & $\begin{array}{r}-0.02644 \\
(0.114)\end{array}$ & $\begin{array}{r}-0.05597 \\
(0.204)\end{array}$ & $\begin{array}{r}-0.01328 \\
(0.203)\end{array}$ \\
\hline 1. Some 2 ndry & $\begin{array}{c}-0.08006^{* \star *} \\
(0.000)\end{array}$ & $\begin{array}{c}-0.00902^{* * *} \\
(0.000)\end{array}$ & $\begin{array}{c}-0.23069 * \\
(0.049)\end{array}$ & $\begin{array}{r}-0.03981 \\
(0.058)\end{array}$ & $\begin{array}{r}-0.02855 \\
(0.855)\end{array}$ & $\begin{array}{r}-0.00323 \\
(0.855)\end{array}$ & $\begin{array}{c}-0.24258 * * * \\
(0.000)\end{array}$ & $\begin{array}{c}-0.05269 * \\
(0.000)\end{array}$ \\
\hline 3. Post 2 ndry & $\begin{array}{c}-0.03462 \star \star \\
(0.006)\end{array}$ & $\begin{array}{c}-0.00402^{\star \star} \\
(0.006)\end{array}$ & $\begin{array}{c}-0.29304 * \\
(0.043)\end{array}$ & $\begin{array}{c}-0.04902 * \\
(0.040)\end{array}$ & $\begin{array}{r}-0.28834 \\
(0.310)\end{array}$ & $\begin{array}{r}-0.02780 \\
(0.254)\end{array}$ & $\begin{array}{r}-0.05653 \\
(0.244)\end{array}$ & $\begin{array}{r}-0.01341 \\
(0.240)\end{array}$ \\
\hline 4. Grad. degree & $\begin{array}{r}-0.02919 \\
(0.213)\end{array}$ & $\begin{array}{r}-0.00340 \\
(0.207)\end{array}$ & $\begin{array}{r}-0.51189 \\
(0.119)\end{array}$ & $\begin{array}{c}-0.07648 * \\
(0.049)\end{array}$ & $\begin{array}{l}0.91441^{\star *} \\
(0.002)\end{array}$ & $\begin{array}{l}0.16907 * \\
(0.020)\end{array}$ & $\begin{array}{r}-0.01208 \\
(0.916)\end{array}$ & $\begin{array}{r}-0.00292 \\
(0.916)\end{array}$ \\
\hline 0. Not working & $\begin{array}{l}-0.07248 * \star \star \\
(0.000)\end{array}$ & $\begin{array}{c}-0.00854 * \star \\
(0.000)\end{array}$ & $\begin{array}{c}-0.75059 \star \star \\
(0.000)\end{array}$ & $\begin{array}{c}-0.10131 * \star \\
(0.000)\end{array}$ & $\begin{array}{c}-0.32270^{*} \\
(0.044)\end{array}$ & $\begin{array}{c}-0.03410 * \\
(0.042)\end{array}$ & $\begin{array}{r}-0.03958 \\
(0.247)\end{array}$ & $\begin{array}{r}-0.00890 \\
(0.246)\end{array}$ \\
\hline 2. Ret | Stud & $\begin{array}{l}-0.36141 * \star \star \\
(0.000)\end{array}$ & $\begin{array}{l}-0.03507 * * * \\
(0.000)\end{array}$ & $\begin{array}{c}-0.80414 * \star \star \\
(0.000)\end{array}$ & $\begin{array}{c}-0.10518 * \star \star \\
(0.000)\end{array}$ & $\begin{array}{c}-0.61751^{\star} \\
(0.016)\end{array}$ & $\begin{array}{c}-0.05419 * \star \\
(0.002)\end{array}$ & $\begin{array}{c}-0.23171 \star \star \star \\
(0.000)\end{array}$ & $\begin{array}{c}-0.04736^{*} \\
(0.000)\end{array}$ \\
\hline 1. Low 338ile & $\begin{array}{r}-0.00879 \\
(0.587)\end{array}$ & $\begin{array}{r}-0.00099 \\
(0.586)\end{array}$ & $\begin{array}{r}-0.14733 \\
(0.315)\end{array}$ & $\begin{array}{r}-0.01749 \\
(0.290)\end{array}$ & $\begin{array}{l}0.38318^{*} \\
(0.011)\end{array}$ & $\begin{array}{l}0.04489 * \\
(0.018)\end{array}$ & $\begin{array}{l}0.03962 \\
(0.387)\end{array}$ & $\begin{array}{l}0.00886 \\
(0.392)\end{array}$ \\
\hline 3. Upp. 338ile & $\begin{array}{l}0.04068 * k \star \\
(0.000)\end{array}$ & $\begin{array}{l}0.00472^{\star \star \star \star} \\
(0.000)\end{array}$ & $\begin{array}{l}0.12177 \\
(0.155)\end{array}$ & $\begin{array}{l}0.01692 \\
(0.153)\end{array}$ & $\begin{array}{r}-0.02212 \\
(0.871)\end{array}$ & $\begin{array}{r}-0.00202 \\
(0.871)\end{array}$ & $\begin{array}{l}0.00958 \\
(0.774)\end{array}$ & $\begin{array}{l}0.00211 \\
(0.774)\end{array}$ \\
\hline Opportunity $=1$ & $\begin{array}{l}0.37507 * \star * \\
(0.000)\end{array}$ & $\begin{array}{l}0.04313^{* * *} \\
(0.000)\end{array}$ & $\begin{array}{l}0.12499 \\
(0.144)\end{array}$ & $\begin{array}{l}0.01685 \\
(0.141)\end{array}$ & $\begin{array}{l}0.20049 \\
(0.148)\end{array}$ & $\begin{array}{l}0.01918 \\
(0.125)\end{array}$ & $\begin{array}{l}0.21324 * \star * \\
(0.000)\end{array}$ & $\begin{array}{l}0.04555 * \\
(0.000)\end{array}$ \\
\hline Know entrep $=1$ & $\begin{array}{l}0.28791 * \star \star \\
(0.000)\end{array}$ & $\begin{array}{l}0.03345 * * * \\
(0.000)\end{array}$ & $\begin{array}{l}0.32576 * \star \star * \\
(0.000)\end{array}$ & $\begin{array}{l}0.04359 * * * \\
(0.000)\end{array}$ & $\begin{array}{l}0.16494 \\
(0.165)\end{array}$ & $\begin{array}{l}0.01690 \\
(0.170)\end{array}$ & $\begin{array}{l}0.24925 * * * \\
(0.000)\end{array}$ & $\begin{array}{l}0.05391 * \\
(0.000)\end{array}$ \\
\hline S.UP skill=1 & $\begin{array}{l}0.60856^{* \star \star} \\
(0.000)\end{array}$ & $\begin{array}{l}0.06190 * \star \star \\
(0.000)\end{array}$ & $\begin{array}{l}0.27587 * \star \\
(0.002)\end{array}$ & $\begin{array}{l}0.03607 * \star \\
(0.001)\end{array}$ & $\begin{array}{r}-0.02984 \\
(0.851)\end{array}$ & $\begin{array}{r}-0.00298 \\
(0.849)\end{array}$ & $\begin{array}{l}0.49545 * \star \star \\
(0.000)\end{array}$ & $\begin{array}{l}0.09853 * * \\
(0.000)\end{array}$ \\
\hline Good choice $=1$ & $\begin{array}{l}0.03898 * \star \star \\
(0.001)\end{array}$ & $\begin{array}{l}0.00446 \text { *** } \\
(0.001)\end{array}$ & $\begin{array}{r}-0.05130 \\
(0.598)\end{array}$ & $\begin{array}{r}-0.00708 \\
(0.604)\end{array}$ & $\begin{array}{l}0.39592 \star \\
(0.014)\end{array}$ & $\begin{array}{l}0.03441^{* *} \\
(0.004)\end{array}$ & $\begin{array}{c}-0.13221 \text { t** } \\
(0.000)\end{array}$ & $\begin{array}{c}-0.03025 * \\
(0.000)\end{array}$ \\
\hline Media image $=1$ & $\begin{array}{r}-0.01237 \\
(0.245)\end{array}$ & $\begin{array}{r}-0.00144 \\
(0.246)\end{array}$ & $\begin{array}{l}0.04255 \\
(0.609)\end{array}$ & $\begin{array}{l}0.00576 \\
(0.608)\end{array}$ & $\begin{array}{l}0.16620 \\
(0.167)\end{array}$ & $\begin{array}{l}0.01658 \\
(0.161)\end{array}$ & $\begin{array}{c}-0.16185 * \star \star \\
(0.000)\end{array}$ & $\begin{array}{c}-0.03663^{*} \\
(0.000)\end{array}$ \\
\hline Fear fail.=1 & $\begin{array}{c}-0.17648 * \star \star \\
(0.000)\end{array}$ & $\begin{array}{c}-0.01969 * \star \star \star \\
(0.000)\end{array}$ & $\begin{array}{l}0.16363 * \\
(0.048)\end{array}$ & $\begin{array}{l}0.02278 \\
(0.053)\end{array}$ & $\begin{array}{l}0.75994 * \star * \\
(0.000)\end{array}$ & $\begin{array}{l}0.05800 * \star \star \\
(0.000)\end{array}$ & $\begin{array}{r}-0.05194 \\
(0.124)\end{array}$ & $\begin{array}{r}-0.01140 \\
(0.120)\end{array}$ \\
\hline & 1671 & 167172 & 2397 & 2397 & 160 & 1603 & 11187 & 11187 \\
\hline seudo & 0.116 & & 0.159 & & 0.185 & & 0.058 & \\
\hline hi-s & 87.2944 & & 227.673 & & 137.62 & & & \\
\hline (c) & -36260.35 & & -600 & & -30 & & & 33.16004 \\
\hline CC proport. & 93.32005 & & 91.19733 & & 93.88646 & & .84848 & \\
\hline
\end{tabular}

(1) p-values in parentheses

(d) for discrete change of dummy variable from 0 to 1
$\star p<0.05, \star \star *<0.01, \star \star \star$
$p<0.001$

There is variation in the magnitude of marginal effects across the global, Pakistan and factor-driven sub-samples for the next variable considered, i.e. how self-confidence in one's own abilities, skills and knowledge translate into entrepreneurial activity. So while this faith increases the likelihood of someone turning entrepreneur by $9 \%$ in factor-driven subsample, the magnitude is a more modest $3.6 \%$ in the case of Pakistan. Nevertheless, there is sufficient evidence available to accept Hypothesis 3. As previously, Bangladesh is the odd one out, with a lack of statistical significance among the dependent and independent variable.

Finally, among noteworthy results, the fear of failure (Hypothesis 4) was found to reduce the chances of an individual engaging in startup activity in the global sample. However, this intuitive relationship was not discovered in any of the other samples. In fact, for the Bangladesh sub-sample, individuals who declared that the fear of failure would be an inhibiting factor were actually more inclined to become entrepreneurs - a puzzle which is beyond the scope of this thesis. Suffice it so say that, with the exception of global sample, there is insufficient evidence from this dataset that individuals in factor-driven economies respond to fear of failure or display risk aversive behavior which mirrors the attitude of their counterparts in developed economies.

Business Review: (2019) 14(2):13-30 
Moving on to the more standard demographic variables, gender presents contrasting findings for Pakistan. While the marginal effects for both factor-driven economies as a group and Bangladesh as a country are statistically significant, and indicate that women in these sub-samples are as much as $3.5 \%$ less likely to become entrepreneurs compared to men, gender appears to be an insignificant factor in Pakistan's case. Thus, there is insufficient evidence for us to accept Hypothesis 5 for Pakistan, based on this particular sample.

With respect to education, in Pakistan, those with no education are at a significant disadvantage compared to those with secondary degrees. A surprising finding for Bangladesh is that individuals with graduate degrees are almost $17 \%$ more likely to become entrepreneurs compared to the base. Comparing with the global sample, where we had failed to accept Hypothesis 6 and its prediction of U-shaped relationship between education and propensity for entrepreneurship, Bangladesh partially satisfies the requirement of most educated individuals being most entrepreneurially inclined; however, its least educated individuals do not reflect the same tendency.

Another striking finding is that while age affects entrepreneurship inclination in a quadratic (non-linear) manner for the global sample, and the marginal effect is statistically significant even at $0.1 \%$ level, this relationship becomes weaker in the case of factor-driven economies. Moreover, it is missing altogether from both the Pakistan and Bangladesh sub-samples; therefore, we fail to accept Hypothesis 7 for these two sub-samples. With reference to household income, this relationship was not statistically significant for any of the sub-samples. Rather, in Bangladesh, a relatively weak positive relationship was found between individuals from lowest one-third of households (in terms of income) and the likelihood of turning entrepreneur. On the whole, there is not enough evidence for us to accept Hypothesis $8^{6}$.

Regarding the impact of work status, individuals who are "not working" and those classified as "students and retirees" are almost $10 \%$ less likely to opt for entrepreneurship compared to full or part time employees in Pakistan-the largest marginal effects across all four samples. This sub-category as a whole reflects very consistent results across countries and regions, giving us ample basis to accept Hypothesis 9.

\section{Learning and policy implications}

Regarding perceptual variables, since opportunity perception increases the probability that someone will create a new business across the global sample and factor-driven sub-sample, a case can be made to provide more forums for the exchange of ideas. In the case of developing countries, individuals have an even greater set of possibilities available to them: in many cases, rather than reinventing the wheel, they can simply observe products and services which have been successfully implemented in developed, innovative countries, make minor

\footnotetext{
6 We were, of course, constrained to consider household incomes rather than the concerned individual's wealth, owing to non-availability of the latter in the dataset, which leaves open a field of inquiry for future research.
} 
alterations to suit the local market and introduce the product/service at home ${ }^{7}$. In this context, individuals in developing countries could benefit from exchange programs or similar platforms to travel to developed countries and witness innovations firsthand. On the flip side, individuals in developed countries would also benefit from travel to developing countries since the latter may represent large, untapped markets with sizeable populations for example, countries in Africa and South Asia. To borrow a concept coined by Prahalad (2006), there is a fortune to be gained at the bottom of the pyramid; an enabling factor is to make entrepreneurs increasingly aware of these opportunities, at home and abroad.

The previous recommendation also ties in neatly to address the finding that personally knowing someone who started a business recently makes an individual more inclined to launch his/her own venture - a finding which is as relevant for Pakistan as it is for factor-driven economies and entrepreneurs across the globe. In addition to one-off conferences and weekend workshops, which can be good starting points to meet new people, personally getting to know someone might require more frequent and sustained interaction, on a near daily basis if possible. Incubation centers, accelerators and other shared workspaces help generate a community-like environment where participants meet and observe each other for prolonged periods of time. Such establishments are encouraged not to work in isolation, but also to open their doors to the general public frequently and share their success stories. They could offer frequent internship and volunteering opportunities. For startups, these interns and volunteers would offer a more flexible, financially feasible alternative to hiring individuals full-time. For interns and volunteers, getting to know entrepreneurs on a personal level might provide the spark they need to consider launching their own ventures.

Building on from another key finding that self-confidence in one's own skills, knowledge and abilities to start a business increases the likelihood of actually launching a venture, the recommendation for colleges and universities offering entrepreneurship development programs is to give equal focus to development of soft skills and general confidence building exercises for students, along with the more traditional modules like business plan development, financing, marketing etc. It is not enough for an aspiring entrepreneur to simply have a good idea for a product or service: communicating this idea with confidence and convincing others that both the idea and the entrepreneur himself/herself have merit is also crucial. Pitching an idea to venture capitalists and investors for funding is just one of many situations where this self-confidence is tested, sometimes quite brutally, with make-or-break consequences for the aspiring entrepreneur. Universities and colleges can also develop a feedback mechanism to estimate the effectiveness of their programs by collecting data relating to self-confidence (of knowledge, skills and abilities) from students at several junctures: at the point of enrolment, regular intervals thereafter as suitable, and finally at the conclusion of the program. This would help determine how effective the program is in molding the perceptions and attitudes of students in line with the desired mindset for entrepreneurs.

With regard to addressing the fear of failure, another significant variable

\footnotetext{
7 Given that they do not engage in any ethical violation or copyright infringement in doing
} so.

Business Review: (2019) 14(2):13-30 
in the global context, it is possible that the mentality of being held back by fear is developed even earlier than the age of eighteen (bearing in mind that the current sample whose responses we have analyzed belong to the 18-64 years age bracket), in which case the corrective interventions also need to be made at a young age. Enterprise development programs for children are a relatively new phenomena, with the idea being, inter alia, to give children a taste of entrepreneurship early on in life. Children who have created successful ventures, no matter how limited the scale or time frame, may have a lower fear of failure to launch a business in future as adults. While it would be premature to declare cause and effect at this stage, the idea appears sound in principle at least. Hence, in areas where they have as yet not been implemented, experimenting with children's enterprise development programs is recommended, again being mindful that data collection would be vital to gauge the success of such interventions ${ }^{8}$.

The finding that full-time working individuals appear more inclined to turn entrepreneur compared to students or retired individuals presents a golden opportunity for progressive companies to tap into. These firms can leverage the power of intrapreneurship to their advantage. Intrapreneurship allows entrepreneurial minded individuals to create and launch new ideas, products or even entirely new divisions within the companies that employ them. This can be a win-win situation for both parties: on the one hand, the company benefits from fresh innovation and also retains its talented employees, who may have eventually left the firm to pursue their business ideas independently had they not been given an opportunity to do so within the firm. On the other hand, the individuals in question also benefit because they need not take on excessive risk of starting a whole new enterprise; also, the established setup, financial backing and expertise they can leverage within the firm can translate into getting the new product/service to the market faster.

\section{Concluding remarks}

This paper enriches our understanding of the factors which influence an individual's decision to turn entrepreneur. In particular, it highlights the role of perceptual variables and makes it evident that without accounting for perceptions and attitudes, we would have only an incomplete picture of entrepreneurship. The cross-country approach adds depth to the findings. For policy-makers who want to encourage more individuals to adopt entrepreneurship as a career path, there are valuable clues in the analysis and proposed recommendations.

At the same time, we are mindful of the study's limitations. For example, data on some important variables like the individual respondent's wealth was not captured, so their potential impact is missing in the analysis. The data is also limited to two years, i.e. 2010 and 2011. In future, combining data from

\footnotetext{
8 An ambitious, but potentially worthwhile, project would be to generate panel data for children who participate in such programs, following their career paths as adults to determine long run impact on fear of failure and, by extension, the decision to engage in entrepreneurship.
} 
several waves to employ a pseudo-panel approach could be a useful approach to tease out the dynamics over time and across countries.

\section{References}

Aldrich HE, Martinez MA (2007) Many are called, but few are chosen: An evolutionary perspective for the study of entrepreneurship. In: Entrepreneurship, Springer, pp 293-311

Arenius P, Minniti M (2005) Perceptual variables and nascent entrepreneurship. Small business economics 24(3):233-247

Backes-Gellner U, Moog P (2013) The disposition to become an entrepreneur and the jacksof-all-trades in social and human capital. The Journal of Socio-Economics 47:55-72

Backman M, Karlsson C (2013) Determinants of entrepreneurship. Is it all about the individual or the region? The Royal Institute of technology Centre of Excellence for Science and

Bandura A (1977) Self-efficacy: toward a unifying theory of behavioral change. Psychological review 84(2):191

Bosma N, Van Praag M, De Wit G, et al (2000) Determinants of successful entrepreneurship

Boyd NG, Vozikis GS (1994) The influence of self-efficacy on the development of entrepreneurial intentions and actions. Entrepreneurship theory and practice 18(4):63-77

Cameron AC, Trivedi PK (2005) Microeconometrics: methods and applications. Cambridge university press

Cooper AC, Woo CY, Dunkelberg WC (1988) Entrepreneurs' perceived chances for success. Journal of business venturing 3(2):97-108

Eckhart J, Shane S (2003) Opportunities and entrepreneurship. Journal of Management $29(3): 333-349$

Evans DS, Jovanovic B (1989) An estimated model of entrepreneurial choice under liquidity constraints. Journal of political economy 97(4):808-827

Fraser S, Greene FJ (2006) The effects of experience on entrepreneurial optimism and uncertainty. Economica 73(290):169-192

Haque NU, et al (2007) Entrepreneurship in pakistan. Tech. rep., East Asian Bureau of Economic Research

Kihlstrom RE, Laffont JJ (1979) A general equilibrium entrepreneurial theory of firm formation based on risk aversion. Journal of political economy 87(4):719-748

Koellinger P, Minniti M, Schade C (2013) Gender differences in entrepreneurial propensity. Oxford bulletin of economics and statistics 75(2):213-234

Langowitz N, Minniti M (2007) The entrepreneurial propensity of women. Entrepreneurship theory and practice 31(3):341-364

Markman GD, Balkin DB, Baron RA (2002) Inventors and new venture formation: The effects of general self-efficacy and regretful thinking. Entrepreneurship theory and practice $27(2): 149-165$

McFadden D, et al (1977) Quantitative methods for analyzing travel behavior of individuals: some recent developments. Institute of Transportation Studies, University of California Berkeley, CA

Poschke M (2013) Who becomes an entrepreneur? labor market prospects and occupational choice. Journal of Economic Dynamics and Control 37(3):693-710

Praag CMV, Ophem HV (1995) Determinants of willingness and opportunity to start as an entrepreneur. Kyklos 48(4):513-540

Prahalad CK (2006) The innovation sandbox. Strategy and Business 44:62

Rasool F, Gulzar A, Naseer S (2012) Drivers of entrepreneurship: linking with economic growth and employment generation (a panel data analysis). The Pakistan Development Review pp 587-605

Shane S (2000) Venkataraman.(2000). The promise of entrepreneurship as a field of research pp $217-226$

Taylor MP (1996) Earnings, independence or unemployment: why become self-employed? Oxford Bulletin of Economics and Statistics 58(2):253-266

Wagner J, Sternberg R (2004) Start-up activities, individual characteristics, and the regional milieu: Lessons for entrepreneurship support policies from german micro data. the annals of regional science $38(2): 219-240$

Business Review: (2019) 14(2):13-30 


\section{Appendix}

Table A1: List of countries that participated in GEM 2010 and GEM 2011 surveys

\begin{tabular}{|c|c|c|c|c|c|c|c|}
\hline \multicolumn{8}{|c|}{ Data from GEM 2010 APS } \\
\hline SN & Countries & $\mathrm{SN}$ & Countries & $\mathrm{SN}$ & Countries & $\mathrm{SN}$ & Countries \\
\hline 1 & US & 31 & Mexico & 1 & US & 31 & Venezuela \\
\hline 2 & Greece & 32 & Argentina & 2 & Greece & 32 & Uruguay \\
\hline 3 & Netherlands & 33 & Brazil & 3 & Netherlands & 33 & Trinidad \& Tobago \\
\hline 4 & Belgium & 34 & Chile & 4 & Belgium & 34 & Jamaica \\
\hline 5 & France & 35 & Colombia & 5 & France & 35 & Russia \\
\hline 6 & Spain & 36 & Guatemala & 6 & Spain & 36 & Hungary \\
\hline 7 & Italy & 37 & Costa Rica & 7 & Switzerland & 37 & Romania \\
\hline 8 & Switzerland & 38 & Bolivia & 8 & UK & 38 & Turkey \\
\hline 9 & UK & 39 & Ecuador & 9 & Denmark & 39 & Lithuania \\
\hline 10 & Denmark & 40 & Uruguay & 10 & Sweden & 40 & Latvia \\
\hline 11 & Sweden & 41 & Trinidad \& Tobago & 11 & Norway & 41 & Croatia \\
\hline 12 & Norway & 42 & Jamaica & 12 & Poland & 42 & Slovenia \\
\hline 13 & Germany & 43 & Russia & 13 & Germany & 43 & Bosnia \& Herzegovina \\
\hline 14 & Portugal & 44 & Hungary & 14 & Portugal & 44 & Czech republic \\
\hline 15 & Ireland & 45 & Romania & 15 & Ireland & 45 & Slovakia \\
\hline 16 & Iceland & 46 & Turkey & 16 & Finland & 46 & Malaysia \\
\hline 17 & Finland & 47 & Latvia & 17 & Algeria & 47 & Australia \\
\hline 18 & Ghana & 48 & Montenegro & 18 & Iran & 48 & Thailand \\
\hline 19 & South Africa & 49 & Croatia & 19 & Pakistan & 49 & Japan \\
\hline 20 & Angola & 50 & Slovenia & 20 & Bangladesh & 50 & South Korea \\
\hline 21 & Uganda & 51 & Bosnia & 21 & $\mathrm{UAE}$ & 51 & China \\
\hline 22 & Zambia & 52 & Macedonia & 22 & Peru & 52 & Taiwan \\
\hline 23 & Tunisia & 53 & Malaysia & 23 & Mexico & & \\
\hline 24 & Egypt & 54 & Australia & 24 & Argentina & & \\
\hline 25 & Iran & 55 & Japan & 25 & Brazil & & \\
\hline 26 & Israel & 56 & South Korea & 26 & Chile & & \\
\hline 27 & Saudi Arabia & 57 & China & 27 & Colombia & & \\
\hline 28 & West Bank \& Gaza & 58 & Vanuatu & 28 & Barbados & & \\
\hline 29 & Pakistan & 59 & Taiwan & 29 & Guatemala & & \\
\hline 30 & Peru & & & 30 & Panama & & \\
\hline
\end{tabular}


Entrepreneurship in Pakistan...

Table A2: Pooled countries list, sorted by regions to reflect geographical representation

\begin{tabular}{|c|c|c|c|c|c|}
\hline \multicolumn{6}{|c|}{ GEM $2010+2011$ (pooled) - Sorted by region } \\
\hline $\mathrm{SN}$ & Countries & region & $\mathrm{SN}$ & Countries & region \\
\hline 1 & US & $\begin{array}{l}\text { US + Western } \\
\text { Europe }\end{array}$ & 36 & Brazil & $\begin{array}{l}\text { Latin America } \\
\text { + Caribbean }\end{array}$ \\
\hline 2 & Greece & $\begin{array}{l}\text { US + Western } \\
\text { Europe }\end{array}$ & 37 & Chile & $\begin{array}{l}\text { Latin America } \\
\text { + Caribbean }\end{array}$ \\
\hline 3 & Netherlands & $\begin{array}{l}\text { US + Western } \\
\text { Europe }\end{array}$ & 38 & Colombia & $\begin{array}{l}\text { Latin America } \\
+ \text { Caribbean }\end{array}$ \\
\hline 4 & Belgium & $\begin{array}{l}\text { US + Western } \\
\text { Europe }\end{array}$ & 39 & Barbados & $\begin{array}{l}\text { Latin America } \\
\text { + Caribbean }\end{array}$ \\
\hline 5 & France & $\begin{array}{l}\text { US + Western } \\
\text { Europe }\end{array}$ & 40 & Guatemala & $\begin{array}{l}\text { Latin America } \\
\text { + Caribbean }\end{array}$ \\
\hline 6 & Spain & $\begin{array}{l}\text { US + Western } \\
\text { Europe }\end{array}$ & 41 & Costa Rica & $\begin{array}{l}\text { Latin America } \\
+ \text { Caribbean }\end{array}$ \\
\hline 7 & Italy & $\begin{array}{l}\text { US + Western } \\
\text { Europe }\end{array}$ & 42 & Panama & $\begin{array}{l}\text { Latin America } \\
\text { + Caribbean }\end{array}$ \\
\hline 8 & Switzerland & $\begin{array}{l}\text { US + Western } \\
\text { Europe }\end{array}$ & 43 & Venezuela & $\begin{array}{l}\text { Latin America } \\
+ \text { Caribbean }\end{array}$ \\
\hline 9 & UK & $\begin{array}{l}\text { US + Western } \\
\text { Europe }\end{array}$ & 44 & Bolivia & $\begin{array}{l}\text { Latin America } \\
+ \text { Caribbean }\end{array}$ \\
\hline 10 & Denmark & $\begin{array}{l}\text { US + Western } \\
\text { Europe }\end{array}$ & 45 & Ecuador & $\begin{array}{l}\text { Latin America } \\
\text { + Caribbean }\end{array}$ \\
\hline 11 & Sweden & $\begin{array}{l}\text { US + Western } \\
\text { Europe }\end{array}$ & 46 & Uruguay & $\begin{array}{l}\text { Latin America } \\
+ \text { Caribbean }\end{array}$ \\
\hline 12 & Norway & $\begin{array}{l}\text { US + Western } \\
\text { Europe }\end{array}$ & 47 & $\begin{array}{l}\text { Trinidad \& } \\
\text { Tobago }\end{array}$ & $\begin{array}{l}\text { Latin America } \\
+ \text { Caribbean }\end{array}$ \\
\hline 13 & Poland & $\begin{array}{l}\text { US + Western } \\
\text { Europe }\end{array}$ & 48 & Jamaica & $\begin{array}{l}\text { Latin America } \\
+ \text { Caribbean }\end{array}$ \\
\hline 14 & Germany & $\begin{array}{l}\text { US + Western } \\
\text { Europe }\end{array}$ & 49 & Russia & Eastern Europe \\
\hline 15 & Portugal & $\begin{array}{l}\text { US + Western } \\
\text { Europe }\end{array}$ & 50 & Hungary & Eastern Europe \\
\hline 16 & Ireland & $\begin{array}{l}\text { US + Western } \\
\text { Europe }\end{array}$ & 51 & Romania & Eastern Europe \\
\hline 17 & Iceland & $\begin{array}{l}\text { US + Western } \\
\text { Europe }\end{array}$ & 52 & Turkey & Eastern Europe \\
\hline 18 & Finland & $\begin{array}{l}\text { US + Western } \\
\text { Europe }\end{array}$ & 53 & Lithuania & Eastern Europe \\
\hline 19 & Ghana & Other Africa & 54 & Latvia & Eastern Europe \\
\hline 20 & Angola & Other Africa & 55 & Montenegro & Eastern Europe \\
\hline 21 & Uganda & Other Africa & 56 & Croatia & Eastern Europe \\
\hline 22 & Zambia & Other Africa & 57 & Slovenia & Eastern Europe \\
\hline 23 & Egypt & MENASA & 58 & Bosnia & Eastern Europe \\
\hline 24 & Pakistan & MENASA & 59 & Macedonia & Eastern Europe \\
\hline 25 & Iran & MENASA & 60 & C Republic & Eastern Europe \\
\hline 26 & Algeria & MENASA & 61 & Slovakia & Eastern Europe \\
\hline 27 & Tunisia & MENASA & 62 & Malaysia & Asia Pacific \\
\hline 28 & Bangladesh & MENASA & 63 & Australia & Asia Pacific \\
\hline 29 & Saudi Arabia & MENASA & 64 & Thailand & Asia Pacific \\
\hline 30 & $\begin{array}{l}\text { West bank \& } \\
\text { Gaza }\end{array}$ & MENASA & 65 & Japan & Asia Pacific \\
\hline 31 & UAE & MENASA & 66 & South Korea & Asia Pacific \\
\hline 32 & Israel & MENASA & 67 & China & Asia Pacific \\
\hline 33 & Peru & $\begin{array}{l}\text { Latin America } \\
+ \text { Caribbean }\end{array}$ & 68 & Vanuatu & Asia Pacific \\
\hline 34 & Mexico & $\begin{array}{l}\text { Latin America } \\
+ \text { Caribbean }\end{array}$ & 69 & Taiwan & Asia Pacific \\
\hline 35 & Argentina & $\begin{array}{l}\text { Latin America } \\
+ \text { Caribbean }\end{array}$ & & & \\
\hline
\end{tabular}

Business Review: (2019) 14(2):13-30 
T. Nadeem et al

Table A3: Pooled countries list, sorted by economic classification

GEM $2010+2011$ (pooled)- Sorted by economic classification

\begin{tabular}{|c|c|c|c|c|c|}
\hline $\mathrm{SN}$ & Countries & econ_cls & $\mathrm{SN}$ & Countries & econ_cls \\
\hline 1 & Ghana & factor-driven & 36 & Barbados & efficiency-driven+ \\
\hline 2 & Uganda & factor-driven & 37 & Uruguay & efficiency-driven+ \\
\hline 3 & Zambia & factor-driven & 38 & $\begin{array}{l}\text { Trinidad \& To- } \\
\text { bago }\end{array}$ & efficiency-driven + \\
\hline 4 & Pakistan & factor-driven & 39 & Russia & efficiency-driven+ \\
\hline 5 & Bangladesh & factor-driven & 40 & Hungary & efficiency-driven+ \\
\hline 6 & $\begin{array}{l}\text { West Bank } \\
\text { \& Gaza }\end{array}$ & factor-driven & 41 & Turkey & efficiency-driven+ \\
\hline 7 & Bolivia & factor-driven & 42 & Lithuania & efficiency-driven+ \\
\hline 8 & Vanuatu & factor-driven & 43 & Latvia & efficiency-driven+ \\
\hline 9 & Angola & factor-driven + & 44 & Croatia & efficiency-driven+ \\
\hline 10 & Iran & factor-driven + & 45 & US & innovation-driven \\
\hline 11 & Algeria & factor-driven + & 46 & Greece & innovation-driven \\
\hline 12 & Saudi Arabia & factor-driven + & 47 & Netherlands & innovation-driven \\
\hline 13 & Guatemala & factor-driven + & 48 & Belgium & innovation-driven \\
\hline 14 & Venezuela & factor-driven + & 49 & France & innovation-driven \\
\hline 15 & Jamaica & factor-driven + & 50 & Spain & innovation-driven \\
\hline 16 & Tunisia & efficiency-driven & 51 & Italy & innovation-driven \\
\hline 17 & Peru & efficiency-driven & 52 & Switzerland & innovation-driven \\
\hline 18 & Colombia & efficiency-driven & 53 & UK & innovation-driven \\
\hline 19 & Costa Rica & efficiency-driven & 54 & Denmark & innovation-driven \\
\hline 20 & Panama & efficiency-driven & 55 & Sweden & innovation-driven \\
\hline 21 & Ecuador & efficiency-driven & 56 & Norway & innovation-driven \\
\hline 22 & Romania & efficiency-driven & 57 & Germany & innovation-driven \\
\hline 23 & Montenegro & efficiency-driven & 58 & Portugal & innovation-driven \\
\hline 24 & Bosnia & efficiency-driven & 59 & Ireland & innovation-driven \\
\hline 25 & Macedonia & efficiency-driven & 60 & Iceland & innovation-driven \\
\hline 26 & Slovakia & efficiency-driven & 61 & Finland & innovation-driven \\
\hline 27 & Malaysia & efficiency-driven & 62 & UAE & innovation-driven \\
\hline 28 & China & efficiency-driven & 63 & Israel & innovation-driven \\
\hline 29 & Thailand & efficiency-driven & 64 & Slovenia & innovation-driven \\
\hline 30 & Poland & efficiency-driven+ & 65 & $\begin{array}{l}\text { Czech Repub- } \\
\text { lic }\end{array}$ & innovation-driven \\
\hline 31 & Egypt & efficiency-driven+ & 66 & Australia & innovation-driven \\
\hline 32 & Mexico & efficiency-driven+ & 67 & Japan & innovation-driven \\
\hline 33 & Argentina & efficiency-driven+ & 68 & South Korea & innovation-driven \\
\hline 34 & Brazil & efficiency-driven+ & 69 & Taiwan & innovation-driven \\
\hline 35 & Chile & efficiency-driven+ & & & \\
\hline
\end{tabular}

Legend: factor-driven+: transitioning from factor-driven to efficiency-driven efficiency-driven + : transitioning from efficiency-driven to innovation-driven 